Центр воєнно-стратегічних досліджень Національного університету оборони України імені Івана Черняховського, Київ

\title{
Погляди на організацію проведення демобілізації в державі
}

Резюме. У статті розглянуто положення нормативно-правових документів у сфері організації демобілізації в державі. Проведено аналіз сучасного стану нормативно-правового поля в контексті підготовки органів державної влади, інших державних органів до проведення демобілізації.

Ключові слова: мобілізаційна підготовка; демобілізація.

Постановка проблеми. Проблема підготовки та проведення демобілізації в державі полягає в тому, що людство, наука i практика насамперед мають досвід та аналізують цей комплекс заходів тільки в контексті демобілізації збройних сил. Велика кількість війн відбувалася без переведення економіки, населення, інших складових на режим роботи та життя в особливих умовах. По-перше, це обумовлено рівнями та змістом воєнних конфліктів, їх тривалістю. По-друге це пов'язано 3 вкрай обмеженою кількістю держав, які мають розвинуту економіку та оборонно-промисловий комплекс (ОПК) 3 резервом потужностей, чисельне населення, гнучку систему управління державою тощо.

У статті пропонується системно розглянути завдання, способи, зміст заходів проведення демобілізації в державі.

Аналіз останніх досліджень i публікацій. В існуючих публікаціях $[1,2]$ обгрунтовано необхідність проведення заходів демобілізації держави через вирішення завдань соціально-економічної сфери. Аналіз досвіду демобілізації промислового виробництва, життя населення в публікаціях не наводиться. Демобілізація збройних сил розглядається в основному через призму розв'язання проблем колишніх військовослужбовців, що без сумніву важливо. Проблемам переведення системи державного управління, а також питанням планування і підготовки підприємств, установ і закладів (далі - підприємств) обороннопромислового комплексу, національної економіки до функціонування в умовах мирного часу після завершення війни не приділено належної уваги.

Метою статті $\epsilon$ визначення та систематизація завдань, способів, заходів демобілізації в державі.

Виклад основного матеріалу. Організація проведення демобілізації в державі - це найскладніший період роботи керівництва держави на завершальному етапі війни.

Це визначається необхідністю одночасного планування та проведення збройної боротьби наприкінці війни, заходів демобілізації, мобілізаційної підготовки до можливої майбутньої війни, будівництва нового, перспективного обрису Збройних Сил України (в іншій організаційно-штатній структурі, 3 іншими умовами дислокації військ (сил)), який грунтується на загрозах, що залишилися або формуються, а також плануванням стратегічного застосування сил оборони держави на їх нейтралізацію. Уважається за доцільне розглядати ці питання у взаємозв'язку.

Діюча нормативно-правова база визначає мобілізацію як комплекс заходів, що здійснюється 3 метою планомірного переведення національної економіки, діяльності органів державної влади, інших державних органів, органів місцевого самоврядування, підприємств, установ і організацій (далі - “система управління державою”) на функціонування в умовах особливого періоду, а Збройних Сил України, інших військових формувань, Оперативнорятувальної служби цивільного захисту - на організацію i штати воєнного часу 3 доукомплектуванням особовим складом, озброєнням, військовою технікою (ОВТ), іншими матеріально-технічними засобами (MT3).

Комплекс заходів демобілізації передбачає їх спрямованість на планомірне переведення національної економіки, системи управління державою на роботу i функціонування в умовах мирного часу, а Збройних Сил України, інших військових формувань, Оперативно-рятувальної служби цивільного захисту - на організацію і штати мирного часу. Проте переведення системи забезпечення життєдіяльності населення на функціонування в умовах мирного часу 
існуючим понятійним апаратом не передбачається, що на погляд автора є помилковим [3].

Вважається за доцільне розглядати демобілізацію як зворотні дії заходам мобілізації в державі:

демобілізація функціонування системи управління державою;

демобілізація Збройних Сил України, інших військових формувань, Оперативнорятувальної служби цивільного захисту;

демобілізація національної економіки;

демобілізація системи забезпечення життєдіяльності населення.

До того ж, демобілізація в державі може бути загальною або частковою. Загальною коли мета війни досягнута, воєнна загроза ліквідована, наближається тривалий час гарантованого миру. Частковою - коли на одному або декількох операційних напрямках воєнна загроза ліквідована, противник отримав воєнну поразку, але мирна угода не укладена.

Демобілізація може бути відкритою або прихованою. Відкритою вона буде у варіанті загальної. Прихованою - у варіанті часткової.

Рішення про проведення демобілізації приймається Президентом України із внесенням його на затвердження Верховною Радою України.

Організація проведення демобілізації, іiі планування та всебічне забезпечення належать до управлінських функцій, а саме:

у сфері демобілізації функціонування системи управління державою - Президенту України, Раді національної безпеки і оборони України, Кабінету Міністрів України, органам державної влади, іншим державним органам, органам місцевого самоврядування, керівництву підприємств, установ і організацій;

у сфері демобілізації Збройних Сил України, інших військових формувань, Оперативно-рятувальної служби цивільного захисту - Президенту України, Раді національної безпеки i оборони України, Кабінету Міністрів України, Міністерству оборони України, Генеральному штабу Збройних Сил України, Міністерству внутрішніх справ України, органам управління інших військових формувань, Міністерству фінансів України, Міністерству охорони здоров'я України, Міністерству інфраструктури України;

у сфері демобілізації національної економіки - Президенту України, Раді національної безпеки і оборони України,
Кабінету Міністрів України, Міністерству розвитку економіки, торгівлі та сільського господарства України, Міністерству фінансів України, Міністерству оборони України, іншим державним органам, органам місцевого самоврядування, керівництву підприємств, установ і організацій;

у сфері демобілізації системи забезпечення життєдіяльності населення Президенту України, Раді національної безпеки i оборони України, Кабінету Міністрів України, Міністерству розвитку економіки, торгівлі та сільського господарства України, Міністерству енергетики та захисту довкілля України, Міністерству інфраструктури України, Міністерству освіти і науки України, Міністерству охорони здоров'я України, Міністерству розвитку громад та територій України, Міністерству соціальної політики України, Міністерству у справах ветеранів, тимчасово окупованих територій та внутрішньо переміщених осіб України, Міністерству фінансів України.

Демобілізація функціонування системи управління державою полягає у проведенні комплексу заходів, що спрямовані на:

розроблення та впровадження планів переведення системи управління державою 3 умов роботи в особливий період на умови роботи мирний час;

підготовку та виконання Указу Президента України про припинення воєнного стану на всій території України або в окремих іï місцевостях;

повідомлення через Генерального секретаря ООН держав-учасниць Міжнародного пакту про громадянські та політичні права про зняття обмежень прав i свобод людини і громадянина в Україні;

припинення дії нормативно-правових актив, які стосуються прав і свобод людини i громадянина, що обмежують їх у зв'язку 3 введенням воєнного стану;

передавання повноти влади від органів військового управління до цивільних органів влади;

підготовку та виконання Указу Президента України про припинення діяльності Ставки Верховного Головнокомандувача;

переведення систем управління, засобів зв'язку, інформаційного забезпечення на роботу в умовах мирного часу;

підвищення ролі державного регулювання у сфері роботи та перебудови економіки на початковому етапі демобілізації 
держави 3 подальшим залученням ринкових інструментів;

отримання досвіду країн світу через систему міжнародного співробітництва у сфері проведення демобілізації держави;

підготовку керівного складу системи управління державою до дій під час демобілізації;

проведення військово-економічних навчань і тренувань у системі управління державою з питань проведення демобілізаціі; оновлення нормативно-правового регулювання у сфері демобілізації (внесення змін та доповнень до нормативно-правових актів);

проведення заходів щодо наукового i методичного забезпечення процесів демобілізації за напрямами;

уточнення сфер діяльності та підготовка системи управління державою до роботи в умовах мирного часу; організація

інформаційного забезпечення органів управління 3 питань демобілізації;

поступове повернення оперативних груп, що були відряджені до інших органів влади для забезпечення взаємодії;

згортання рухомих, позаміських пунктів управління, засобів зв'язку та автоматизації; постановка технічних засобів управління на зберігання; відміну особливого режиму в’їду i виїзду, обмежень свободи пересування населення та громадян інших країн; відміну заборони діяльності політичних партій, громадських організацій;

зняття обмежень прав і свобод людини, повернення звичайного робочого часу, відпусток, оплати праці, лікарняних тощо; роботу з роботодавцями, спрямовану на вивільнення робочих місць для демобілізованих, пошук посад 3 меншим навантаженням для поранених і хворих;

вирішення уповноваженими органами питань 3 амністуванням дезертирів у випадках їх працевлаштування;

організацію роботи щодо видачі субсидій, надання матеріальної допомоги демобілізованим, оформлення кредитів на індивідуальне будівництво житла, отримання житлових приміщень;

переведення органів системи управління державою на штати (штатні розписи) мирного часу.

Проведення наведених заходів ставить за мету концентрацію можливостей системи управління для зосередження зусиль держави i суспільства на налагодженні мирного життя та розвитку країни.

Демобілізація в державі має розглядатися та плануватися як етап оновлення всіх складових існування суспільства. Інакше складно буде пояснити нащадкам доцільність витрат фантастичних ресурсів та часу.

Демобілізація Збройних Сил України, інших військових формувань, Оперативнорятувальної служби цивільного захисту полягає в проведенні комплексу заходів, що спрямовані на:

підготовку та впровадження плану проведення демобілізації Збройних Сил України, інших військових формувань, Оперативно-рятувальної служби цивільного захисту;

підготовку організаційних директив щодо складу, чисельності, штатів, умов дислокації органів військового управління, 3'єднань, військових частин, військових формувань в режимі мирного часу;

проведення організаційних заходів щодо розформування, переформування, передислокації органів військового управління, з’єднань, військових частин;

проведення стратегічного планування застосування Збройних Сил України, інших військових формувань на виклики майбутнього;

підготовка директиви на загальне уточнення мобілізаційних планів, планів відмобілізування та приведення в бойову готовність органів військового управління, 3'єднань, військових частин, видів (сил) Збройних Сил України, військових формувань, передбачених законами України, що залишаються (створюються) у складі мирного часу;

проведення загального уточнення мобілізаційних планів, планів відмобілізування та приведення в бойову готовність органів військового управління, 3'єднань, військових частин, складу мирного часу після їх прибуття до місць постійної дислокації, а також планів проведення мобілізації людських і транспортних ресурсів військових комісаріатів;

розвиток

військово-технічного співробітництва 3 країнами-партнерами у сфері спільної підготовки, розвитку ОВТ та способів їх застосування;

проведення звільнення особового складу, відповідно до рішення про проведення демобілізації, яке прийнято Президентом України; 


\section{ВОСННО-ПРИКЛАДНІ ПИТАННЯ СИСТЕМНОГО АНАЛІЗУ ТА МАТЕМАТИЧНОГО МОДЕЛЮВАННЯ}

надання пріоритету у процесі комплектуванні військ (сил) персоналу 3 кращою фізичною підготовкою, 3 відмінним станом здоров'я, звільнення 3 військової служби військовослужбовців старших за віком;

скорочення кількості та чисельності військових частин забезпечення (обслуговування) у складі військ (сил); відкриття зон повітряного руху над районами колишніх бойових дій; проведення заходів боротьби 3 “демобілізаційними” настроями у військовому середовищі;

повернення власникам техніки та об’єктів, що були передані під час мобілізації Збройним Силам України, іншим військовим формуванням;

проведення заходів утилізації (реалізації) надлишкового ОВТ та МТ3;

відправку на ремонтні заводи (заводивиробники) ОВТ, які відпрацювали міжремонтні строки;

проведення роботи щодо заборони продажу спиртного на шляхах руху військових ешелонів, організацію забезпечення продовольством у дорозі, надання медичної допомоги;

забезпечення військовослужбовців звільнених 3 військової служби, які стали на облік у військових комісаріатах, продуктами харчування і предметами першої необхідності до працевлаштування.

Проведення цих заходів ставить за мету концентрацію зусиль Збройних Сил України, інших військових формувань, Оперативнорятувальної служби цивільного захисту на переведення їх можливостей 3 кількісних показників на якісні, вирішення соціальних питань військовослужбовців, зменшення витрат ресурсів на утримання військ (сил).

Демобілізація національної економіки полягає в проведенні комплексу заходів, що спрямовані на:

розроблення та впровадження плану демобілізації національної економіки;

переведення виробничих потужностей певних підприємств 3 випуску воєнної продукції на задоволення потреб держави мирного часу;

будівництво нових заводів і фабрик;

розширення асортименту продукції, валових показників, робіт, послуг в інтересах задоволення потреб населення;

поновлення

(налагодження)

міжнародних економічних зв'язків, кооперації у виробництві сучасної продукції; пошук, придбання потрібних технологій, обладнання для відродження підприємств, транспорту медичних закладів, виробництва критичної, конкурентної продукції;

згортання спеціальних формувань, які були передані до складу військових формувань;

згортання спеціальних формувань, які були створені для задоволення потреб галузей національної економіки;

переведення фінансової системи держави на функціонування в умовах мирного часу;

переведення банківської системи держави на функціонування в умовах мирного часу;

пошук та ефективне використання кредитів і позик міжнародних банків, кредитних установ, урядів країн світу на відновлення промисловості, транспорту, сільського господарства, житла тощо;

ефективне використання цільових державних позик у населення на виконання програм демобілізації;

погашення кредитів і позик, які були отримані напередодні проведення мобілізації в державі та в особливий період від світових джерел;

поступове погашення державних позик у населення, що були отримані напередодні проведення мобілізації та в особливий період;

переведення підприємств, установ та організацій на роботу за стандартами мирного часу;

переведення сил та засобів технічного прикриття об'єктів, споруд i транспортних магістралей оборонного i важливого загальнодержавного значення до роботи в умовах мирного часу;

укладання договорів (контрактів) на виконання підприємствами, установами і організаціями поставок матеріально-технічних ресурсів, виконання робіт та надання послуг підприємствам та населенню в мирний час;

поновлення (створення) мобілізаційних резервів матеріально-технічних i сировинних ресурсів;

поновлення, створення (розвиток) системи мобілізаційних потужностей у промисловості;

проведення роботи по укладанню (розірванню) договорів (контрактів) на виконання підприємствами мобілізаційних завдань (замовлень);

надання державою допомоги

підприємствам через кредитування 
сировиною, електроенергією, паливом, транспортними послугами тощо;

організацію роботи транспортної системи для забезпечення перевезення 3'єднань, військових частин, ОВТ у райони постійної дислокації, місць складування та зберігання;

переведення транспортної системи на роботу в умовах мирного часу, насамперед, для забезпечення роботи економіки;

розбронювання робочої сили, підготовка та проведення перерозподілу трудових ресурсів для забезпечення повноцінної роботи підприємств національної економіки та забезпечення потреб населення;

масове створення робочих місць у містах 3 порушеною інфраструктурою (прибирання вулиць, розбирання зруйнованих будівель, будівництво доріг, шкіл, дитячих садочків тощо);

переведення редакцій друкованих засобів масової інформації і телерадіоорганізацій до роботи в умовах мирного часу;

пошук компромісу під час вирішення соціально-виробничих конфліктів між профспілками та керівниками (власниками) підприємств;

боротьбу із саботажем на виробництві, транспорті та у сфері надання послуг населенню.

Проведення цих заходів ставить за мету перерозподіл фінансових, матеріальних, людських, наукових, інформаційних, сировинних, організаційних ресурсів, які забезпечували інтереси оборони держави на задоволення потреб поновлення та розвитку економіки.

Доцільно уважно розглянути досвід управління та координації роботи органів державної влади під час проведення заходів демобілізації економіки в Німеччині (19181919 рр.) через єдиний координаційний орган - відомство економічної демобілізації (демобілізаційне управління). Цікавим також вважається формування та діяльність за рівнями влади комітетів 3 демобілізації в Росії (1921 - 1924 рp.).

Демобілізація системи забезпечення життєдіяльності населення полягає у проведенні комплексу заходів, що спрямовані на: розроблення та впровадження плану переведення системи забезпечення життєдіяльності населення на функціонування в мирних умовах;

організацію фінансової допомоги підприємствам системи забезпечення життєдіяльності населення в поновлені потужностей, модернізації обладнання, поширені можливостей у виконанні робіт та наданні послуг;

формуванні кас взаємодопомоги, кредитних організацій, фондів для підтримки населення, підприємців, роботодавців; організацію роботи 3 виплати допомоги по безробіттю;

організацію роботи щодо працевлаштування інвалідів (одного на кожну сотню працюючих);

організацію взаємодії служб зайнятості населення, рекрутингових компаній 3 підприємствами, роботодавцями; повернення власникам техніки та об’єктів, що були передані для забезпечення евакуації населення 3 прикордонних районів та районів техногенних i природних катастроф;

повернення населення, що було евакуйоване 3 прикордонних районів та районів техногенних і природних катастроф до місць постійного проживання;

планування та поступове переведення системи 3 нормованого забезпечення населення продовольчими та непродовольчими товарами, медичним обслуговуванням, послугами зв'язку, транспорту, комунальними та побутовими послугами до монетарного або безкоштовного отримання послуг;

впровадження заходів соціального регулювання, державний контроль ціноутворення;

недопущення безробіття серед колишніх військовослужбовців.

Проведення наведених заходів ставить за мету переформатування системи забезпечення життєдіяльності населення 3 умов роботи в особливий період до роботи в умовах мирного життя. Варіант структури державного управління заходами демобілізації національної економіки наведено на рис. 1. 




Рис. 1. Структурна схема державного управління заходами демобілізації національної економіки (варіант)

Видатки на заходи демобілізації виділяються відповідно до вимог Бюджетного кодексу України та інших нормативноправових актів.

Цікавим є те, що в Законі України "Про мобілізаційну підготовку та мобілізацію” питання демобілізації згадується декілька раз, a саме: надаючи визначення поняття “демобілізація" (ст. 1) та у переліку повноважень Президента України (ст. 11). Водночас, реальний зміст, способи, форми демобілізації в державі (органах державного управління, військових формуваннях, галузях, підприємствах, установах, організаціях) та особливості ऑiі проведення в законодавстві України не визначені.

Слід звернути увагу, що на сьогодні сферу мобілізації регламентують близько двадцяти законів України, десяти актів Президента України, тридцяти актів Кабінету Міністрів України та понад двадцять наказів відповідних центральних органів виконавчої влади. Водночас, більшість керівних документів 3 мобілізаційної підготовки, мобілізації та демобілізації в державі, мають обмежений доступ необгрунтовано (таємні, цілком таємні), що робить їх недоступними i незрозумілими для більшості громадян
України, не забезпечує належного балансу індивідуальних і державних інтересів.

Висновки. Для підвищення ефективності правового регулювання у сфері мобілізації пропонується як першочерговий напрям удосконалення законодавства про мобілізацію підготувати та прийняти нову редакцію комплексного Закону України "Про мобілізаційну підготовку та мобілізацію”. Під час його розроблення доцільно зосередитись на збільшенні кількості норм прямої дії закону, зменшенні бланкетних норм, а також скороченні кількості нормативно-правових актів 3 обмеженим доступом, зокрема актів відомчого характеру. Після системного оновлення вказаного закону, Кабінету Міністрів України слід забезпечити планомірне скасування застарілих та послідовне прийняття центральними органами виконавчої влади нових нормативно-правових актів відкритого характеру, що визначатимуть лише перелік і форми відповідних документів без ї змістовного (кількісно-якісних показників) наповнення.

\section{СПИСОК ВИКОРИСТАННОЇ ЛІТЕРАТУРИ}

1. Бочков Е. А. Социально-экономические аспекти демобилизации Красной армии в первой половине 1920-х годов. URL: 
https://cyberleninka.ru/article/n/sotsialnoekonomicheskie-aspekty-demobilizatsii-krasnoyarmii-v-pervoy-polovine-1920-h-godov (дата звернення: 04.02.2020).

2. Тимофеева Т. Ю. Проблемы войны и мира. URL: http://auroragroup.eu/library_get_pdf.php?Id=35089

(дата звернення: 02.03.2020).

3. Про мобілізаційну підготовку та мобілізацію: Закон України від 21.10.1993 № 3543-XII. URL: https://zakon.rada.gov.ua/laws/show/3543-12 (дата звернення: 27.01.2020).
4. Супян Б. В. Создание военно-промышленного комплекса США. Реформирование оборонной промышленности США после Второй мировой войны. URL: http://economy-ru.com/mirovayaekonomika-uchebnik/sozdanie-voennopromyishlennogo-kompleksa-ssha-52124.html (дата звернення: 27.01.2020).

5. Гріненко О. І., Кутовий О. П., Шапталенко М. I. Мобілізаційна підготовка національної економіки України. Оборонний вісник. 2017. № 6. С. 8-11.

Стаття надійшла до редакційної колегії 11.03.2020

\section{Views on the organization of demobilization in the state}

\section{Annotation}

The problem of preparation and conduct of demobilization in the state is that humanity; science and practice mainly have experience and analyze this set of measures only in the context of demobilization of the Armed Forces. Numerous wars which took place last time were without the transfer of the economy, population and other components to the mode of operation in a "Special Period" firstly due to the level of military conflict and their length, secondly, with an extremely limited number of states that has an economy and a Military-Industrial Complex with a reserve of capacity, large population, flexible system of government etc.

The purpose of the article is to define and systematize the tasks, methods, measures of demobilization in the state.

The organization of demobilization in the state is the most difficult period of work of the state leadership at the final stage of the war. The set of demobilization measures envisages their focus on the systematic transfer of the national economy, the system of government to work and functioning in peacetime. The Armed Forces of Ukraine and other formations, operational and rescue services of civil defense are switched to the organization of peacetime mode. But the transfer of the system of ensuring the livelihood of the population to operate in peacetime by existing legislation is not interpreted.

A variant of the structure of state management of measures to demobilize the national economy is presented in the paper.

It should be noted that currently the field of mobilization is regulated by a number of state documents (twenty laws of Ukraine, ten acts of the President of Ukraine, thirty acts of the Cabinet of Ministers of Ukraine and more than twenty orders of the relevant central executive bodies). At the same time, most documents on mobilization training, mobilization and demobilization in the state have limited access, which makes them inaccessible and incomprehensible to most people in the country and does not provide a proper balance of individual and state interests. In order to increase the effectiveness of legal regulation in the field of mobilization, it is proposed to improve the legislation on state mobilization and to prepare and adopt a new version of the Law of Ukraine "On mobilization training and mobilization".

Keywords: mobilization preparation; demobilization. 